\title{
ESTIMASI EMISI GAS RUMAH KACA (GRK) KEGIATAN PENGELOLAAN SAMPAH DI KELURAHAN KARANG JOANG, BALIKPAPAN
}

\author{
Eka Masrifatus Anifah' ${ }^{1)}$, Intan Dwi Wahyu Setyo Rini ${ }^{1)}$, Rachmat Hidayat ${ }^{1)}$, \\ Muhammad Ridho ${ }^{1)}$ \\ 1) Program Studi Teknik Lingkungan, Institut Teknologi Kalimantan, Balikpapan \\ Email : ekamasrifatus@ lecturer.itk.ac.id
}

\begin{abstract}
Abstrak
Kegiatan pengelolaan sampah di Kota Balikpapan pada saat ini yaitu pengangkutan dari sumber dan penimbunan di tempat pemrosesan akhir (TPA) Manggar. Pengangkutan sampah dari sumber dan penimbunan sampah di TPA menghasilkan gas rumah kaca seperti gas karbondioksida dan metana. Data timbulan dan komposisi yang digunakan dalam estimasi emisi gas rumah kaca didapatkan dengan sampling di kawasan permukiman Kelurahan Karang Joang, Balikpapan. Metode sampling timbulan dan komposisi dilakukan sesuai dengan Standar Nasional Indonesia (SNI) 19-3964-1994. Estimasi emisi gas rumah kaca dihitung berdasarkan metode The Intergovernmental Panel on Climate Change (IPCC) Tahun 2019 Tier 1. Rata-rata timbulan sampah perumahan di Kelurahan Karang Joang adalah 0,25 kg/orang/hari. Komposisi sampah didominasi sampah organik dan kertas dengan persentase rata-rata 49,09\% dan 21,82\%. Emisi total gas rumah kaca dari proses pengangkutan sampah adalah 460,11 kg ekuivalen $\mathrm{CO}_{2} /$ tahun/ton sampah. Emisi gas rumah kaca dari proses pemrosesan akhir sampah dihitung berdasarkan tiga skenario pengelolaan sampah yaitu penimbunan sampah di TPA, penimbunan dan pembakaran sampah secara terbuka, serta daur ulang dan pengomposan sampah. Proses pemrosesan akhir dengan cara penimbunan menghasilkan emisi gas rumah kaca $3237 \mathrm{~kg}$ ekuivalen $\mathrm{CO}_{2}$ per ton sampah basah yang ditimbun. Proses penimbunan dan pembakaran sampah menghasilkan emisi $2433 \mathrm{~kg}$ ekuivalen $\mathrm{CO}_{2}$ per ton sampah basah yang dibakar dan ditimbun. Untuk mengurangi jumlah emisi yang ditimbulkan dari proses pengangkutan dan penimbunan sampah di TPA, perhitungan emisi dengan skenario pengomposan sampah organik dan daur ulang sampah dilakukan. Proses pengomposan menghasilkan emisi $386 \mathrm{~kg}$ ekuivalen $\mathrm{CO}_{2}$ per ton sampah. Skenario ketiga, proses pengomposan dan penimbunan sampah residu menghasilkan emisi gas rumah kaca sebesar $913 \mathrm{~kg}$ ekuivalen $\mathrm{CO}_{2}$ per ton sampah. Proses daur ulang dan pengomposan sampah dapat menurunkan emisi gas rumah kaca sebesar 62,34\% dari kondisi BAU.
\end{abstract}

Kata kunci: Emisi Gas Rumah Kaca, IPCC, Pemrosesan Akhir Sampah, Pengangkutan Sampah, Pengomposan

\begin{abstract}
Current waste management processes in Balikpapan city are waste collection from waste generation sources and waste disposal in Manggar landfill. Waste collection and disposal in landfill generates greenhouse gases such as carbon dioxide and methane. Data of waste generation and composition that were used in the estimation of greenhouse gases emission were collected with sampling in the residential area of Karang Joang, Balikpapan. Sampling of waste generation and composition was carried out based on Indonesia National Standard (SNI) SNI 19-3964-1994. The estimation of greenhouse emissions was calculated based on the Intergovernmental Panel on Climate Change (IPCC) 2019 Tier 1 method. Waste generation of the residential area of Karang Joang is 0,25 $\mathrm{kg} / \mathrm{capita/day}$. The composition of waste is dominated by organic and paper waste with average percentage of $49.09 \%$ and $21.82 \%$, respectively. Greenhouse gas emission from waste collection was 460,11 equivalent $\mathrm{CO}_{2}$ /year/ton of collected waste. Greenhouse gas emission of landfilling was determined based on three scenarios of waste management, landfilling, open burning, and recycling with composting. The final disposal of waste by landfilling generates greenhouse gas emissions of $3237 \mathrm{~kg}$ equivalent $\mathrm{CO}_{2}$ per tonne of dumped wet waste. Open burning of waste generates greenhouse gas emissions of $2433 \mathrm{~kg}$ equivalent $\mathrm{CO}_{2}$ per tonne of openly burned wet waste. For reducing greenhouse gases emission from waste collection and landfilling, scenarios of organic waste composting and waste recycling were calculated. Composting produces greenhouse gas emissions of $386 \mathrm{~kg}$ equivalent $\mathrm{CO}_{2}$ per tonne of waste. Composting with landfilling of residual waste produced $913 \mathrm{~kg}$ equivalent $\mathrm{CO}_{2}$ per tonne of waste. Recycling and composting can reduce greenhouse gas emissions by 62,34\% from Bussiness As Usual (BAU) condition.
\end{abstract}

Keywords: Composting, Greenhouse Gases Emission, IPCC, Waste Collection, Waste Disposal Dikirim/submitted: 19 Oktober 2020

Diterima/accepted: 10 Januari 2021 


\section{PENDAHULUAN}

Peningkatan gas rumah kaca (GRK) merupakan salah satu pemicu terjadinya peningkatan temperatur bumi yang menyebabkan terjadinya pemanasan global. Salah satu sumber penghasil gas rumah kaca adalah kegiatan pengelolaan sampah yang menyumbang sebesar $4 \%$ emisi gas rumah kaca yang ada di bumi (Vergara and Tchobanoglous, 2012). Sumber terbesar emisi gas rumah kaca dari kegiatan pengelolaan sampah berasal dari proses pengangkutan sampah dari sumber ke tempat penimbunan dan penimbunan sampah di TPA.

Proses pengangkutan sampah dari sumber ke TPS atau dari TPS ke TPA pada umumnya menggunakan kendaraan pengangkut pick-up atau truk. Kendaraan bermotor pengangkut sampah menggunakan bahan bakar fosil dalam operasionalnya. Pembakaran bahan bakar fosil menghasilkan gas karbondioksida $\left(\mathrm{CO}_{2}\right)$ yang merupakan salah satu gas rumah kaca. Estimasi gas rumah kaca yang dihasilkan dari pengangkutan sampah adalah $9.4-368 \mathrm{~kg} \mathrm{CO}_{2}$ ekuivalen ( $\mathrm{CO}_{2}$-eq) per ton sampah yang diangkut (Eisted et al., 2009). Besarnya emisi $\mathrm{CO}_{2}$ dari kegiatan pengangkutan sampah bergantung pada metode, jarak pengangkutan, jenis, kapasitas kendaraan pengangkutan, dan jumlah bahan bakar yang digunakan (Chaerul et al., 2020).

Metode pemrosesan akhir sampah yang umum dilakukan di Indonesia adalah penimbunan sampah di TPA. Pada kondisi anaerobik, timbunan sampah menghasilkan gas metana $\left(\mathrm{CH}_{4}\right)$ yang merupakan salah satu gas rumah kaca. Sampah organik merupakan penghasil emisi gas metana terbesar pada proses penimbunan sampah di TPA. Sampah organik memiliki faktor emisi $\mathrm{CH}_{4}$ sebesar 0,42-0,47 $\mathrm{kg} \mathrm{CH}_{4}$ per berat sampah organik yang ditimbun (Kustiasih et al., 2014). Gas metana mempunyai global warming potential (GWP) sebesar 34 kali lebih besar dibandingkan gas karbondioksida (Myhre et al., 2013).

Kota Balikpapan adalah salah satu kota dengan kepadatan penduduk tinggi di provinsi Kalimantan timur. Kota Balikpapan memiliki penduduk 645.727 jiwa yang setiap harinya menghasilkan sampah (Badan Pusat Statistik Kota Balikpapan, 2019). Pada periode tahun 2017-2018, kota Balikpapan menghasilkan sampah sebesar 457,93 ton/hari. Permukiman menyumbang sampah sebesar 70,30\% dari total sampah kota Balikpapan (Kementerian Lingkungan Hidup dan Kehutanan, 2020). Pada umumnya, sampah yang dihasilkan di sumber dikumpulkan di Tempat pembuangan Sementara (TPS). Dari TPS yang tersebar di Kota Balikpapan, sampah diangkut ke Tempat Pemrosesan Akhir (TPA) Manggar untuk dilakukan pemrosesan akhir. 
Timbulan sampah yang dihasilkan Kota Balikpapan akan diangkut dan ditimbun di TPA Manggar yang memiliki luas area penimbunan 10 Ha sampai penutupan. Pertumbuhan jumlah timbulan sampah yang terus meningkat menyebabkan sel penimbunan semakin sedikit. Di sisi lain, penimbunan sampah menghasilkan gas metana yang merupakan salah satu penyebab pemanasan global. Praktik pembakaran sampah terbuka oleh masyarakat masih banyak ditemukan di Kota Balikpapan. Berdasarkan hasil korespondensi, 50\% responden penduduk di Kelurahan Karang Joang melakukan pemrosesan akhir sampah dengan cara membakar karena kurang efektinya pengangkutan sampah ke TPA (Rachman and Matsumoto, 2015). Kota Balikpapan memiliki satu Tempat Pengolahan Sampah Terpadu (TPST) di Kelurahan Gunung Bahagia dengan recovery factor untuk sampah kertas, plastik, logam dan kaca sebesar $84 \%$ (Cahya and Pandebesie, 2017). Komposisi sampah organik yang tinggi menyebabkan TPST belum optimal untuk mereduksi sampah yang masuk ke TPA. Proses pengomposan diperlukan untuk mereduksi sampah organik yang dihasilkan permukiman. Tiga skenario pemrosesan akhir sampah yaitu penimbunan sampah di TPA, pembakaran sampah secara terbuka dan proses pengomposan disimulasikan untuk mengestimasi emisi gas rumah kaca yang dihasilkan.

\section{METODE PENELITIAN}

Pengumpulan data dalam penelitian ini didapatkan dengan cara melakukan kegiatan observasi langsung ke lapangan. Lokasi sampling data merupakan daerah permukiman di Kelurahan Karang Joang, Balikpapan. Peta lokasi sampling ditunjukkan pada Gambar 1. Perumahan Nirmala, Pondok Joang Indah, dan Kumala dipilih sebagai lokasi sampling mewakili jenis perumahan menengah dan menengah atas. Data jumlah bahan bakar, rute dan jarak pengangkutan didapatkan dengan cara routing rute pengangkutan dan wawancara kepada petugas pengangkut sampah di lokasi sampling. Data jumlah timbulan dan komposisi sampah didapatkan dengan cara melakukan pengukuran secara langsung.

Metode pengukuran timbulan dan komposisi sampah berdasarkan pada Standar Nasional Indonesia (SNI) 19-3964-1994 (Badan Standarisasi Nasional, 1994). Pengambilan contoh sampel sampah dilakukan selama 8 hari berturut-turut pada tiga lokasi sampling. Untuk mengukur timbulan sampah, sampah yang terkumpul diukur berat dan volume menggunakan wadah pengukur dengan volume 40 liter. Setelah dilakukan pengukuran berat dan volume, sampah dipisahkan berdasarkan komponen komposisi sampah. Perhitungan timbulan dan komposisi sampah berdasarkan timbulan sampah rata-rata perumahan di lokasi sampling. 


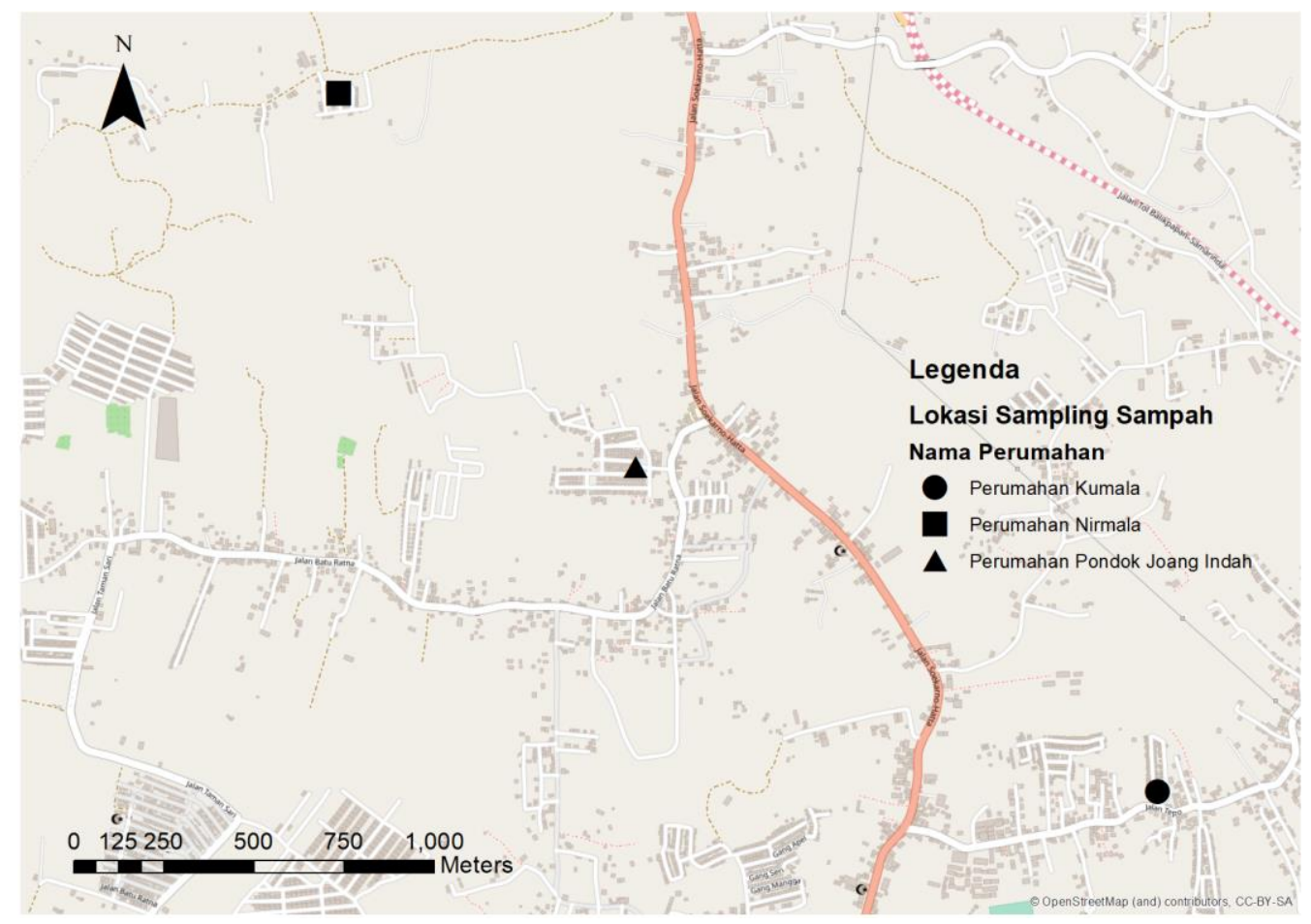

Gambar 1. Lokasi sampling sampah di Kelurahan Karang Joang, Balikpapan

Estimasi potensi emisi gas karbondioksida $\left(\mathrm{CO}_{2}\right)$ hasil pembakaran bahan bakar fosil bergantung pada banyak dan jenis bahan bakar yang dikonsumsi. Estimasi emisi dihitung berdasarkan metode tier- 1 dengan angka default faktor emisi. Metode tier-1 digunakan karena belum tersedianya data faktor emisi di wilayah studi. Persamaan 1 umum digunakan untuk estimasi emisi $\mathrm{CO}_{2}$ dari pembakaran bahan bakar.

$$
\text { Emisi } \mathrm{CO}_{2} / \mathrm{CH}_{4} / \mathrm{N}_{2} \mathrm{O}=\Sigma_{\mathrm{a}}\left(\mathrm{Fuel}_{\mathrm{a}} \times \mathrm{EF}_{\mathrm{a}}\right)
$$

(IPCC, 2019)

Emisi $=$ emisi $\mathrm{CO}_{2} / \mathrm{CH}_{4} / \mathrm{N}_{2} \mathrm{O}$ dari pembakaran bahan bakar

Fuel $_{\mathrm{a}}=$ bahan bakar yang dikonsumsi (TJ)

$\mathrm{EF}_{\mathrm{a}} \quad=$ faktor emisi $(\mathrm{kg} / \mathrm{TJ})$

a $\quad=$ jenis bahan bakar yang dikonsumsi

Gas metana $\left(\mathrm{CH}_{4}\right)$ yang dihasilkan dari proses penimbunan sampah permukiman dihitung berdasarkan jumlah dan komposisi sampah yang dibuang atau ditimbun ke dalam TPA. Estimasi potensi gas metana $\left(\mathrm{CH}_{4}\right)$ yang dihasilkan dari proses penimbunan sampah dapat diperkirakan menggunakan persamaan 2 dan persamaan 3.

$$
\mathrm{L}_{\mathrm{o}}=\mathrm{DDOC}_{\mathrm{m}} \cdot \mathrm{F} \cdot \frac{16}{12}
$$

(IPCC, 2019) 
$\mathrm{L}_{\mathrm{o}} \quad=$ potensi gas $\mathrm{CH}_{4}$ yang dihasilkan $\left(\mathrm{Gg} \mathrm{CH}_{4}\right)$

$\mathrm{DDOC}_{\mathrm{m}}=$ massa karbon organik yang terdegradasi dan terdekomposisi $(\mathrm{kg})$

$\mathrm{F} \quad=$ fraksi gas $\mathrm{CH}_{4}$ dari gas landfill yang dihasilkan.

$16 / 12=$ ratio berat molekul $\mathrm{CH}_{4} / \mathrm{C}$

$$
\mathrm{DDOC}_{\mathrm{m}}=\mathrm{W} \cdot \mathrm{DOC} \cdot \mathrm{DOC}_{\mathrm{f}} \cdot \mathrm{MCF}
$$

(IPCC, 2019)

$\mathrm{DDOC}_{\mathrm{m}}=$ karbon organik yang terdegradasi dan terdekomposisi $(\mathrm{kg})$

$\mathrm{W} \quad=$ massa sampah basah yang dibuang $(\mathrm{kg})$

DOC $=$ fraksi karbon organik yang terdegradasi

$\mathrm{DOC}_{\mathrm{f}}=$ fraksi karbon organik yang terdekomposisi

$\mathrm{MCF}=$ faktor koreksi $\mathrm{CH}_{4}$ pada dekomposisi aeobik

Emisi gas rumah kaca dari pembakaran sampah secara terbuka dihitung berdasarkan perkiraan kandungan karbon dalam sampah yang dibakar dikalikan dengan faktor oksidasi dan fraksi karbon fosil yang dioksidasi. Data aktivitas pembakaran terbuka adalah jumlah dan komposisi sampah yang dibakar secara terbuka. Data kandungan berat kering, kandungan jumlah karbon, fraksi karbon fosil dan faktor oksidasi yang digunakan dalam perhitungan adalah nilai default tier 1. Persamaan 4 menunjukkan emisi gas $\mathrm{CO}_{2}$ yang dihasilkan dari pembakaran terbuka sampah adalah,

$$
\text { Emisi }=\Sigma_{\mathrm{i}}\left(\mathrm{SW}_{\mathrm{i}} \times \mathrm{dm}_{\mathrm{i}} \times \mathrm{CF}_{\mathrm{i}} \times \mathrm{FCF}_{\mathrm{i}} \times \mathrm{OF}_{\mathrm{i}}\right) \times \frac{44}{12}
$$

(IPCC, 2019),

emisi $=$ emisi $\mathrm{CO}_{2}$ dalam tahun inventori $(\mathrm{Gg} / \mathrm{tahun})$

$\mathrm{SW}_{\mathrm{i}} \quad=$ jumlah sampah yang dihasilkan dalam tahun inventori $(\mathrm{Gg} / \mathrm{tahun})$

$\mathrm{dm}_{\mathrm{i}} \quad=$ fraksi berat kering dari jumlah sampah yang dihasilkan

$\mathrm{CF}_{\mathrm{i}}=$ fraksi total karbon di dalam berat kering sampah

$\mathrm{FCF}_{\mathrm{i}}=$ fraksi karbon fossil di dalam total karbon

$\mathrm{OF}_{\mathrm{i}} \quad=$ faktor oksidasi

$44 / 12$ = faktor konversi dari $\mathrm{C}$ ke $\mathrm{CO}_{2}$

Emisi $\mathrm{CH}_{4}$ dari pembakaran terbuka adalah hasil dari pembakaran tidak sempurna sampah. Gas $\mathrm{CH}_{4}$ terbentuk karena terdapat karbon di dalam sampah yang tidak teroksidasi. Perhitungan emisi $\mathrm{CH}_{4}$ dihitung berdasarkan persamaan 5 .

$$
\text { Emisi } \mathrm{CH}_{4}=\Sigma_{\mathrm{i}}\left(\mathrm{IW}_{\mathrm{i}} \times \mathrm{EF}_{\mathrm{i}}\right) \times 10^{-6}
$$


(IPCC, 2019)

emisi = emisi gas $\mathrm{CH}_{4}$ yang dihasilkan dari pembakaran terbuka $(\mathrm{Gg} / \mathrm{tahun})$

$\mathrm{IW}_{\mathrm{i}}=$ jumlah sampah yang dibakar secara terbuka $(\mathrm{Gg} / \mathrm{tahun})$

$\mathrm{EF}_{\mathrm{i}}=$ faktor emisi $\mathrm{CH}_{4}(\mathrm{~kg} \mathrm{CH} / \mathrm{Gg}$ sampah$)$

$10^{-6}=$ faktor konversi dari giga gram ke kilogram

Pengomposan merupakan salah satu proses biologis pengolahan sampah organik. Emisi gas $\mathrm{CH}_{4}$ dari proses pengomposan dihitung berdasarkan persamaan 6 .

$$
\text { Emisi } \mathrm{CH}_{4} / \mathrm{N}_{2} \mathrm{O}=\left(\mathrm{M}_{\mathrm{i}} \times \mathrm{EF}_{\mathrm{i}}\right) \times 10^{-3}-R
$$

(IPCC, 2019),

Emisi $=$ total gas $\mathrm{CH}_{4}$ atau $\mathrm{N}_{2} \mathrm{O}$ yang dihasilkan dari proses pengomposan $(\mathrm{Gg})$

$\mathrm{Mi} \quad=$ jumlah sampah yang dikomposkan $(\mathrm{Gg})$

$\mathrm{EF}_{\mathrm{i}} \quad$ = faktor emisi $\mathrm{CH}_{4} / \mathrm{N}_{2} \mathrm{O}\left(\mathrm{kg} \mathrm{CH}_{4} / \mathrm{Gg}\right.$ sampah $)$

$\mathrm{R} \quad=$ total emisi yang recovery $(\mathrm{Gg})$

\section{HASIL DAN PEMBAHASAN}

\subsection{Timbulan Dan Komposisi Sampah}

Data timbulan dan komposisi sampah merupakan data awal yang digunakan dalam mengestimasi gas rumah kaca dari kegiatan pengelolaan sampah. Timbulan sampah pada lokasi penelitian ini ditunjukkan pada Tabel 1. Perumahan Nirmala yang merupakan perumahan kategori menengah atas menghasilkan sampah 0,33 kg/orang/hari. Nilai ini adalah nilai tertinggi jika dibandingakan dengan perumahan lainnya yang termasuk kategori perumahan menengah. Timbulan sampah untuk kategori perumahan menengah adalah 0,22 dan 0,21 $\mathrm{kg} /$ orang/hari. Nilai timbulan ini hampir sama dengan penelitian timbulan sampah permukiman perumahan di Surabaya yaitu 0,27 kg/orang/hari (Ratya and Herumurti, 2017).

Tabel 1. Timbulan sampah permukiman di Kelurahan Karang Joang, Balikpapan

\begin{tabular}{lrrr}
\hline Perumahan & $\begin{array}{c}\text { Timbulan } \\
\text { (kg/orang/hari) }\end{array}$ & $\begin{array}{c}\text { Timbulan } \\
\text { (L/orang/hari) }\end{array}$ & $\begin{array}{c}\text { Jumlah sampah } \\
\text { (ton/tahun) }\end{array}$ \\
\hline Nirmala & 0,33 & 4,42 & 9,067 \\
\hline Pondok Joang Indah & 0,22 & 2,12 & 17,685 \\
\hline Kumala & 0,21 & 3,13 & 5,421 \\
\hline
\end{tabular}

Data komposisi sampah sangat diperlukan untuk mengetahui potensi gas rumah kaca yang dihasilkan dari kegiatan pemrosesan akhir sampah. Data komposisi sampah juga diperlukan untuk menganalisis pemilihan metode pemrosesan akhir sampah yang tepat agar tidak 
menghasilkan emisi gas rumah kaca yang tinggi. Komposisi sampah untuk perumahan Nirmala, Pondok Joang Indah dan Kumala ditunjukkan pada Gambar 2, Gambar3 dan Gambar 4 secara berurutan. Dari tiga perumahan lokasi sampling dapat diketahui bahwa komposisi terbesar sampah adalah sampah organik. Komposisi sampah organik tertinggi berasal dari perumahan kategori menengah yaitu perumahan Pondok Joang Indah dan Kumala dengan persentase $52,0 \%$ dan $51,1 \%$. Perumahan Nirmala yang termasuk perumahan kelas menengah atas menghasilkan sampah organik sebesar $44,4 \%$. Sampah organik rumah tangga ini didominasi dari sampah sisa sayuran dan sisa makanan. Komposisi terbesar tipikal sampah Indonesia adalah sampah organik yang memerlukan kecepatan dalam pengelolaan karena mudah membusuk (Damanhuri, 2010).

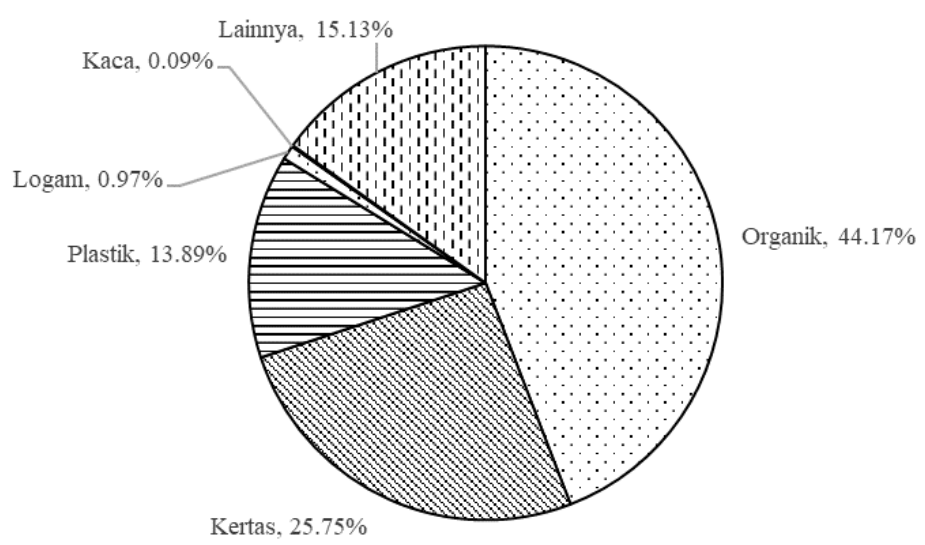

Gambar 2. Komposisi sampah perumahan Nirmala

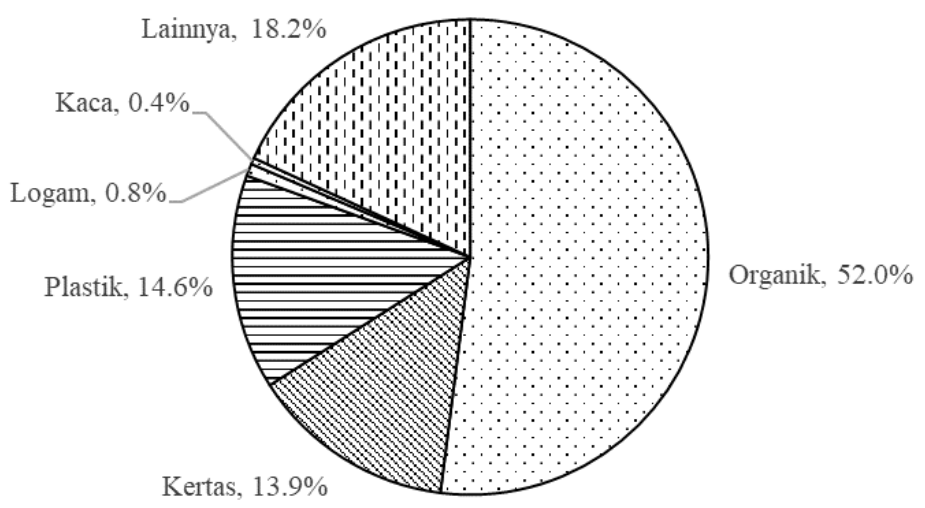

Gambar 3. Komposisi sampah perumahan Pondok Joang Indah 


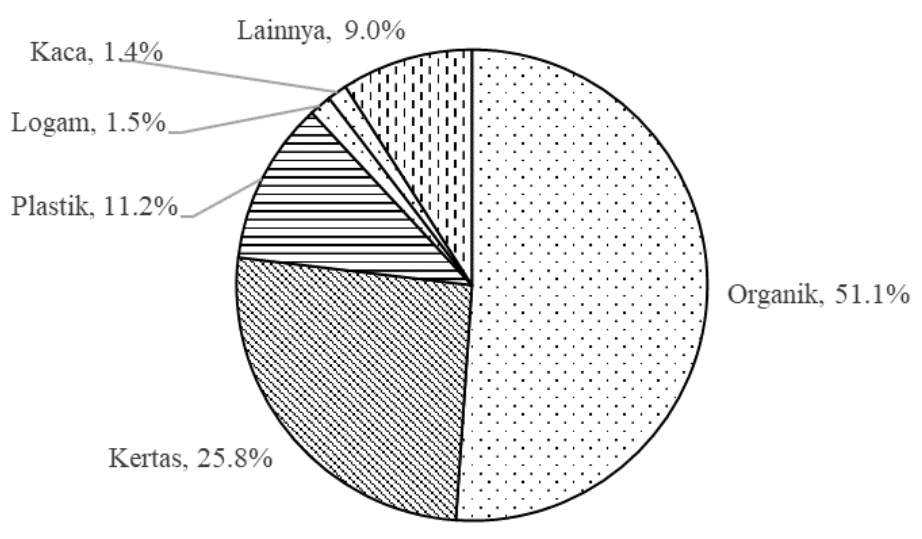

Gambar 4. Komposisi sampah perumahan Kumala

\subsection{Emisi Pengangkutan Sampah}

Emisi gas rumah kaca dari kegiatan pengangkutan sampah perumahan di Kelurahan Karang Joang ditunjukkan pada Tabel 2. Jarak pengangkutan di perumahan Nirmala merupakan jarak terjauh tetapi bahan bakar yang dibutuhkan cukup kecil yaitu 0,40 liter pertalite/hari.

Perumahan Nirmala menggunakan dua jenis kendaran yaitu gerobak dan sepeda motor untuk mengangkut sampah ke TPS. Pengangkutan sampah dari rumah ke rumah menggunakan gerobak dorong, apabila sampah sudah terkumpul diangkut menggunakan sepeda motor ke TPS. Perumahan Pondok Joang Indah membutuhkan bahan bakar jenis pertalite sebanyak 4,06 L/hari. Penggunaan bahan bakar yang tinggi disebabkan oleh kendaraan pengangkut sampah adalah pick up dengan kondisi kurang pemeliharan rutin dan umur kendaaran yang sudah lama. Kendaraan yang kurang mendapatkan perawatan akan menghasilkan emisi gas buang termasuk gas karbondioksida yang tinggi (Kusumawati et al., 2013) Perumahan Kumala menggunakan sepeda motor untuk mengangkut sampah ke TPS dan memiliki jarak pengangkutan ke TPS $1311 \mathrm{~km} / \mathrm{hari}$.

Emisi gas rumah kaca dihitung berdasarkan jumlah bahan bakar. Jenis bahan bakar yang digunakan di tiga lokasi sampling adalah pertalite. Nilai kalor yang digunakan dalam perhitungan adalah nilai default kalor bensin $33 \times 10^{-6} \mathrm{TJ} /$ liter (Kementerian Lingkungan Hidup, 2012). Pembakaran bahan bakar fosil menghasilkan beberapa macam gas yang didominasi gas karbondioksida. Faktor emisi default untuk gas $\mathrm{CO}_{2}$ dari proses pembakaran premium atau pertamax adalah $69.300 \mathrm{~kg} / \mathrm{TJ}$ bahan bakar (IPCC, 2019). Nilai ini dapat digunakan untuk mengestimasi emisi gas karbondiokasida, karena perbedaan persentase 
volume gas buang yang dihasilkan dari pembakaran berbagai jenis bahan bakar adalah $1 \%$. Persentase volume gas karbondioksida yang dihasilkan dari pembakaran premium, pertalite, dan pertamax adalah 7\%,6\%, dan 5\% secara berturut-turut (Ningrat et al., 2016).

Emisi gas rumah kaca dari kegiatan pengangkutan sampah di Perumahan Pondok Joang Indah adalah 285,16 kg ekuivalen $\mathrm{CO}_{2} /$ tahun/ton sampah yang diangkut. Emisi yang tinggi disebabkan kendaraan yang sudah tidak layak dipakai dan kurang perawatan. Emisi terendah dihasilkan oleh kegiatan pengangkutan sampah di perumahan Nirmala. Penggunaan kendaraan yang tidak membutuhkan bahan bakar dapat menurunkan emisi yang dihasilkan per ton sampah yang diangkut. Namun, diperlukan pembiayaan tenaga kerja untuk mengangkut sampah dari sumber penghasil sampah ke TPS

Tabel 2. Emisi gas rumah kaca dari kegiatan pengangkutan sampah permukiman Karang Joang, Balikpapan

\begin{tabular}{lrrrr}
\hline Jenis Perumahan & $\begin{array}{c}\text { Jarak } \\
\text { Pengangkutan } \\
\text { (km/hari) }\end{array}$ & $\begin{array}{c}\text { Konsumsi } \\
\text { bahan bakar } \\
\text { (L/hari) }\end{array}$ & $\begin{array}{c}\text { eq CO } \\
\text { (kg/tahun) }\end{array}$ & $\begin{array}{c}\text { eq CO } \\
\text { (kg/tahun/ton sampah) }\end{array}$ \\
\hline Nirmala & 2092 & 4,06 & 343,89 & 19,44 \\
\hline Pondok Joang Indah & 2544 & 0,40 & 3492,61 & 385,16 \\
\hline Kumala & 1311 & 0,35 & 300,90 & 55,51 \\
\hline
\end{tabular}

\subsection{Emisi Pemrosesan Akhir Sampah}

Skenario pertama yang akan digunakan untuk mengestimasi jumlah gas rumah kaca adalah semua sampah yang telah diangkut kemudian akan ditimbun di tempat pemrosesan akhir sampah. Selama proses penimbunan sampah, kondisi anaerobik pada tempat penimbunan menyebabkan terbentuk gas metana. Estimasi jumlah pembentukan gas metana dalam proses penimbunan ditentukan berdasarkan data faktor emisi gas rumah kaca. Nilai DOC default untuk sampah organik dan sampah kertas yang digunakan dalam estimasi emisi gas rumah kaca adalah 0,15 dan 0,4 dari berat sampah basah. Nilai DOCf default untuk sampah organik dan sampah kertas adalah 0,7 dan 0,5. Faktor koreksi metana (MCF) yang digunakan pada perhitungan emisi gas metana adalah 0,5 (IPCC, 2019). Nilai MCF digunakan dalam estimasi berdasarkan TPA Manggar Balikpapan yaitu proses penimbunan terkelola dengan baik dengan kondisi semi aerobik. Metode penimbunan TPA Manggar adalah sanitary landfill dengan tanah penutup yang dilengkapi dengan sistem pengendali gas, saluran lindi dan instalasi pengolahan air lindi (Purwaningrum et al., 2014). Fraksi gas $\mathrm{CH}_{4}$ dari gas landfill yang digunakan dalam estimasi adalah 50\% (IPCC, 2019). 
Emisi gas metana yang ditimbulkan dari proses penimbunan sampah di lokasi sampling dapat dilihat pada Tabel 3, Tabel 4, dan Tabel 5.

Tabel 3. Emisi gas rumah kaca dari kegiatan penimbunan sampah permukiman Perumahan Nirmala

\begin{tabular}{lrrrrrrrr}
\hline $\begin{array}{c}\text { Jenis } \\
\text { Sampah }\end{array}$ & $\begin{array}{c}\text { Jumlah } \\
\text { Sampah } \\
(\mathbf{k g} / \text { tahun) }\end{array}$ & DOC $^{*}$ & DOCf $^{*}$ & MCF $^{*}$ & $\begin{array}{c}\text { DDOCm } \\
\text { (kg/tahun) }\end{array}$ & $\mathbf{F}^{*}$ & $\begin{array}{c}\mathbf{C H}_{4} \\
\text { (kg/tahun) }\end{array}$ & $\begin{array}{c}\text { eq CO } \\
\text { (kg/tahun) }\end{array}$ \\
\hline Organik & 7811,47 & 0,15 & 0,70 & 0,50 & 410,10 & 0,50 & 273,40 & 9295,65 \\
\hline Kertas & 4553,41 & 0,40 & 0,50 & 0,50 & 455,34 & 0,50 & 303,56 & 10321,07 \\
\hline Plastik & 2456,93 & 0,00 & 0,50 & 0,50 & 0,00 & 0,50 & 0,00 & 0,00 \\
\hline Logam & 171,72 & 0,00 & 0,50 & 0,50 & 0,00 & 0,50 & 0,00 & 0,00 \\
\hline Kaca & 15,59 & 0,00 & 0,50 & 0,50 & 0,00 & 0,50 & 0,00 & 0,00 \\
\hline Lainnya & 2676,66 & 0,00 & 0,50 & 0,50 & 0,00 & 0,50 & 0,00 & 0,00 \\
\hline Total & $\mathbf{1 7 6 8 5 , 7 7}$ & & & & & & $\mathbf{5 7 6 , 9 6}$ & $\mathbf{1 9 6 1 6 , 7 1}$ \\
\hline *(IPCC, 2019) & & & & & & & &
\end{tabular}

Tabel 4. Emisi gas rumah kaca dari kegiatan penimbunan sampah permukiman Perumahan Pondok Joang Indah

\begin{tabular}{|c|c|c|c|c|c|c|c|c|}
\hline $\begin{array}{l}\text { Jenis } \\
\text { Sampah }\end{array}$ & $\begin{array}{c}\text { Jumlah } \\
\text { Sampah } \\
\text { (kg/tahun) }\end{array}$ & DOC $^{*}$ & DOCf* & MCF $^{*}$ & $\begin{array}{c}\text { DDOCm } \\
\text { (kg/tahun) }\end{array}$ & $\mathbf{F}$ & $\begin{array}{c}\mathrm{CH}_{4} \\
\text { (kg/tahun) }\end{array}$ & $\underset{(\mathrm{kg} / \text { tahun })}{\text { eq } \mathrm{CO}_{2}}$ \\
\hline Organik & 4715,81 & 0,15 & 0,70 & 0,50 & 247,58 & 0,50 & 165,05 & 5611,81 \\
\hline Kertas & 1263,83 & 0,40 & 0,50 & 0,50 & 126,38 & 0,50 & 84,26 & 2864,67 \\
\hline Plastik & 1326,12 & 0,00 & 0,50 & 0,50 & 0,00 & 0,50 & 0,00 & 0,00 \\
\hline Logam & 76,13 & 0,00 & 0,50 & 0,50 & 0,00 & 0,50 & 0,00 & 0,00 \\
\hline Kaca & 39,18 & 0,00 & 0,50 & 0,50 & 0,00 & 0,50 & 0,00 & 0,00 \\
\hline Lainnya & 1646,83 & 0,00 & 0,50 & 0,50 & 0,00 & 0,50 & 0,00 & 0,00 \\
\hline Total & 9067,89 & & & & & & 249,31 & 8476,49 \\
\hline
\end{tabular}

*(IPCC, 2019)

Tabel 5. Emisi gas rumah kaca dari kegiatan penimbunan sampah permukiman Perumahan Kumala

\begin{tabular}{lrrrrrrrr}
\hline $\begin{array}{c}\text { Jenis } \\
\text { Sampah }\end{array}$ & $\begin{array}{c}\text { Jumlah } \\
\text { Sampah } \\
\text { (kg/tahun) }\end{array}$ & DOC $^{*}$ & DOCf* & MCF $^{*}$ & $\begin{array}{c}\text { DDOCm } \\
\text { (kg/tahun) }\end{array}$ & $\mathbf{F}^{*}$ & $\begin{array}{c}\mathbf{C H}_{4} \\
\text { (kg/tahun) }\end{array}$ & $\begin{array}{c}\text { eq CO } \mathbf{2} \\
\text { (kg/tahun) }\end{array}$ \\
\hline Organik & 2769,84 & 0,15 & 0,70 & 0,50 & 145,42 & 0,50 & 96,94 & 3296,11 \\
\hline Kertas & 1398,12 & 0,40 & 0,50 & 0,50 & 139,81 & 0,50 & 93,21 & 3169,07 \\
\hline Plastik & 607,48 & 0,00 & 0,50 & 0,50 & 0,00 & 0,50 & 0,00 & 0,00 \\
\hline Logam & 82,35 & 0,00 & 0,50 & 0,50 & 0,00 & 0,50 & 0,00 & 0,00 \\
\hline Kaca & 73,63 & 0,00 & 0,50 & 0,50 & 0,00 & 0,50 & 0,00 & 0,00 \\
\hline Lainnya & 489,58 & 0,00 & 0,50 & 0,50 & 0,00 & 0,50 & 0,00 & 0,00 \\
\hline Total & $\mathbf{5 4 2 1 , 0 1}$ & & & & & & $\mathbf{1 9 0 , 1 5}$ & $\mathbf{6 4 6 5 , 1 9}$ \\
\hline *(IPCC, 2019) & & & & & & & &
\end{tabular}


Penimbunan sampah dari perumahan Nirmala menghasilkan emisi gas metana tertinggi yaitu $576,96 \mathrm{~kg} \mathrm{CH} /$ tahun atau $19616,71 \mathrm{~kg}$ ekuivalen $\mathrm{CO}_{2}$ per tahun karena jumlah timbulan sampah yang dihasilkan tinggi. Dari Tabel 3, 4, dan 5 dapat diestimasikan bahwa Perumahan Nirmala, Pondok Joang Indah dan Kumala menghasilkan emisi gas rumah kaca sebesar 1109, 935, dan 1193 ekuivalen $\mathrm{CO}_{2}$ /ton sampah yang ditimbun di TPA. Emisi gas rumah kaca per ton sampah yang ditimbun tinggi di perumahan Kumala disebabkan oleh komposisi sampah organik dan kertas yang mencapai $76 \%$. Nilai ini lebih tinggi jika dibandingan komposisi sampah organik dan kertas perumahan Nirmala serta Pondok Joang Indah.

Proses pembakaran sampah secara terbuka oleh masyarakat masih banyak ditemukan. Pembakaran terbuka sampah permukiman masih dilakukan karena biaya yang cukup murah dan tidak membutuhkan waktu yang lama untuk memusnahkan sampah. Pembakaran secara terbuka adalah proses membakar sampah di ruang terbuka dengan kondisi proses rendah oksigen serta tanpa kontrol gas dan partikulat yang dihasilkan. Proses pembakaran tanpa pengendalian emisi menyebabkan gas dan partikulat langsung diemisikan ke udara ambien. Proses pembakaran sampah secara terbuka menghasilkan gas-gas seperti gas karbondioksida, metana, karbonmonoksida. Potensi emisi gas metana dan gas karbondioksida dari proses pembakaran sampah global adalah 4,5\% dan 1\% (Wiedinmyer et al., 2014). Selain gas rumah kaca, pembakaran sampah secara terbuka menghasilkan partikulat dan senyawa-senyawa yang berbahaya bagi kesehatan yaitu Polycyclic Aromatic Hydrocarbon (PAHs), Polychlorinated Biphenyls (PCB), Polychlorinated Dibenzodioxins (PCDD), Polychlorinated Dibenzofuran (PCDF) dan benzena (Cogut, 2016). Paparan jangka pendek senyawa-senyawa tersebut dapat menyebabkan gangguan pernafasan dan penyakit kulit.

Skenario kedua dalam pemrosesan akhir sampah adalah pembakaran sampah. Asumsi sampah yang dibakar sebesar 50\%. Jumlah sampah yang masuk ke TPA Manggar pada Tahun 2017 sekitar 128,94 ton (Banaget et al., 2020). Persentase nilai ini lebih rendah dari 50\% total timbulan sampah Kota Balikpapan pada periode Tahun 2017-2018. Emisi gas rumah kaca yang ditimbulkan jika sampah permukiman dibakar secara terbuka ditunjukkan pada Tabel 6, Tabel 7 dan Tabel 8. Berdasarkan tabel tersebut dapat diketahui bahwa gas karbondioksida merupakan emisi terbesar dibandingkan gas $\mathrm{CH}_{4}$ dan $\mathrm{N}_{2} \mathrm{O}$. Perumahan Nirmala menghasilkan emisi ekuivalen $\mathrm{CO}_{2}$ paling tinggi karena jumlah sampah yang dihasilkan paling besar. Kandungan karbon fosil yang tinggi yaitu 75\% pada sampah plastik menyebabkan sampah plastik menjadi penyumbang tertinggi gas karbondioksida pada proses pembakaran terbuka. 
Tabel 6. Emisi gas rumah kaca dari kegiatan pembakaran sampah permukiman Perumahan Nirmala

\begin{tabular}{lrrrrrrrrr}
\hline $\begin{array}{c}\text { Jenis } \\
\text { Sampah }\end{array}$ & $\begin{array}{c}\text { Jumlah } \\
\text { Sampah } \\
\text { (kg/tahun) }\end{array}$ & $\mathbf{d m}^{*}$ & $\mathbf{C F}^{*}$ & $\mathbf{F C F}^{*}$ & $\mathbf{O F}^{*}$ & $\begin{array}{c}\mathbf{C O}_{2} \\
\text { (kg/tahun) }\end{array}$ & $\begin{array}{c}\mathbf{C H}_{4} \\
\text { (kg/tahun) }\end{array}$ & $\begin{array}{c}\mathbf{N}_{2} \mathbf{O} \\
(\mathbf{k g} / \text { tahun) }\end{array}$ & $\begin{array}{c}\text { Total eq } \\
\mathbf{C O}_{2} \\
\text { (kg/tahun) }\end{array}$ \\
\hline Organik & 3905,73 & 0,40 & 0,38 & 0,00 & 0,71 & 0,00 & 25,39 & 0,59 & 1037,75 \\
\hline Kertas & 2276,71 & 0,90 & 0,46 & 0,01 & 0,71 & 24,54 & 14,80 & 0,34 & 629,46 \\
\hline Plastik & 1228,46 & 1,00 & 0,75 & 1,00 & 0,71 & 2398,57 & 7,99 & 0,18 & 2724,98 \\
\hline Logam & 85,86 & 1,00 & 0,00 & 0,00 & 0,71 & 0,00 & 0,56 & 0,01 & 22,81 \\
\hline Kaca & 7,79 & 1,00 & 0,00 & 0,00 & 0,71 & 0,00 & 0,05 & 0,00 & 2,07 \\
\hline Lainnya & 1338,33 & 0,90 & 0,03 & 1,00 & 0,71 & 94,07 & 8,70 & 0,20 & 449,67 \\
\hline Total & $\mathbf{8 8 4 2 , 8 9}$ & & & & & $\mathbf{2 5 1 7 , 1 8}$ & $\mathbf{5 7 , 4 8}$ & $\mathbf{1 , 3 3}$ & $\mathbf{4 8 6 6 , 7 4}$ \\
\hline *(IPCC 2019$)$
\end{tabular}

Tabel 7. Emisi gas rumah kaca dari kegiatan pembakaran sampah permukiman Perumahan Pondok Joang Indah

\begin{tabular}{|c|c|c|c|c|c|c|c|c|c|}
\hline $\begin{array}{l}\text { Jenis } \\
\text { Sampah }\end{array}$ & $\begin{array}{c}\text { Jumlah } \\
\text { Sampah } \\
\text { (kg/tahun) }\end{array}$ & $\mathbf{d m}^{*}$ & $\mathbf{C F}^{*}$ & $\mathbf{F C F}^{*}$ & $\mathrm{OF}^{*}$ & $\begin{array}{c}\mathrm{CO}_{2} \\
(\mathrm{~kg} / \text { tahun })\end{array}$ & $\underset{\text { (kg/tahun) }}{\mathrm{CH}_{4}}$ & $\begin{array}{c}\mathrm{N}_{2} \mathrm{O} \\
\text { (kg/tahun) }\end{array}$ & $\begin{array}{c}\text { Total eq } \\
\mathrm{CO}_{2} \\
\text { (kg/tahun) }\end{array}$ \\
\hline Organik & 2357,91 & 0,40 & 0,38 & 0,00 & 0,71 & 0,00 & 15,33 & 0,35 & 626,50 \\
\hline Kertas & 631,91 & 0,90 & 0,46 & 0,01 & 0,71 & 6,81 & 4,11 & 0,09 & 174,71 \\
\hline Plastik & 663,06 & 1,00 & 0,75 & 1,00 & 0,71 & 1294,62 & 4,31 & 0,10 & 1470,80 \\
\hline Logam & 38,06 & 1,00 & 0,00 & 0,00 & 0,71 & 0,00 & 0,25 & 0,01 & 10,11 \\
\hline Kaca & 19,59 & 1,00 & 0,00 & 0,00 & 0,71 & 0,00 & 0,13 & 0,00 & 5,20 \\
\hline Lainnya & 823,42 & 0,90 & 0,03 & 1,00 & 0,71 & 57,88 & 5,35 & 0,12 & 276,66 \\
\hline Total & 4533,94 & & & & & 1359,31 & 29,47 & 0,68 & 2563,98 \\
\hline
\end{tabular}

Tabel 8. Emisi gas rumah kaca dari kegiatan pembakaran sampah permukiman Perumahan Kumala

\begin{tabular}{|c|c|c|c|c|c|c|c|c|c|}
\hline $\begin{array}{c}\text { Jenis } \\
\text { Sampah }\end{array}$ & $\begin{array}{c}\text { Jumlah } \\
\text { Sampah } \\
\text { (kg/tahun) }\end{array}$ & $\mathbf{d m}^{*}$ & $\mathbf{C F}^{*}$ & $\mathbf{F C F}^{*}$ & OF* & $\begin{array}{c}\mathrm{CO}_{2} \\
\text { (kg/tahun) }\end{array}$ & $\begin{array}{c}\mathrm{CH}_{4} \\
\text { (kg/tahun) }\end{array}$ & $\begin{array}{c}\mathrm{N}_{2} \mathrm{O} \\
(\mathrm{kg} / \text { tahun })\end{array}$ & $\begin{array}{c}\text { Total eq } \\
\mathrm{CO}_{2} \\
\text { (kg/tahun) }\end{array}$ \\
\hline Organik & 1384,92 & 0,40 & 0,38 & 0,00 & 0,71 & 0,00 & 9,00 & 0,21 & 367,97 \\
\hline Kertas & 699,06 & 0,90 & 0,46 & 0,01 & 0,71 & 7,53 & 4,54 & 0,10 & 193,27 \\
\hline Plastik & 303,74 & 1,00 & 0,75 & 1,00 & 0,71 & 593,06 & 1,97 & 0,05 & 673,76 \\
\hline Logam & 41,17 & 1,00 & 0,00 & 0,00 & 0,71 & 0,00 & 0,27 & 0,01 & 10,94 \\
\hline Kaca & 36,82 & 1,00 & 0,00 & 0,00 & 0,71 & 0,00 & 0,24 & 0,01 & 9,78 \\
\hline Lainnya & 244,79 & 0,90 & 0,03 & 1,00 & 0,71 & 17,21 & 1,59 & 0,04 & 82,25 \\
\hline Total & 2710,51 & & & & & 617,80 & 17,62 & 0,41 & 1337,98 \\
\hline
\end{tabular}

Komposisi sampah organik, kertas dan plastic yang tinggi sangat dimungkinan untuk melakukan daur ulang serta pengomposan di sumber penghasil sampah. Proses daur ulang yang dilakukan di sumber dapat mengurangi emisi dari proses pengangkutan sampah ke TPA dan penimbunan di TPA. Proses pengomposan menghasilkan emisi gas metana dengan faktor emisi 
$4 \mathrm{~kg} \mathrm{CH}_{4} / \mathrm{kg}$ dan $0,3 \mathrm{~kg} \mathrm{~N}_{2} \mathrm{O} / \mathrm{kg}$ sampah organik yang dikomposkan. Faktor emisi yang cukup kecil menyebabkan jumlah emisi gas metana yang dihasilkan lebih kecil jika dibandingkan dengan penimbunan sampah organik di TPA. Skenario ketiga adalah proses pengomposan sampah organik dan daur ulang sampah kertas, plastik serta logam dengan faktor reduksi masing-masing $80 \%$. Sampah residu yang dihasilkan dari proses daur ulang dan pengomposan akan ditimbun di TPA. Emisi gas rumah kaca yang dihasilkan jika sampah organik dikomposkan ditunjukkan pada Tabel 9. Jumlah sampah yang dikomposkan adalah 3125, 1886, dan 1385 kg sampah organik untuk Perumahan Nirmala, Pondok Joang Indah, dan Kumala. Emisi tertinggi gas rumah kaca per ton sampah pada proses pengomposan adalah Perumahan Pondok Joang Indah dan Perumahan Kumala dikarenakan komposisi sampah organik yang tinggi jika dibandingkan dengan Perumahan Nirmala. Emisi gas rumah kaca ini cukup kecil jika dibandingkan pemrosesan akhir sampah organik dengan cara penimbunan di TPA atau pembakaran terbuka.

Tabel 9. Emisi gas rumah kaca dari kegiatan pengomposan dan daur ulang sampah permukiman

\begin{tabular}{lrrrr}
\hline Perumahan & $\begin{array}{c}\mathbf{C H}_{4} \\
\text { (kg/tahun) }\end{array}$ & $\begin{array}{c}\mathbf{N}_{2} \mathbf{O} \\
(\mathbf{k g} / \text { tahun })\end{array}$ & $\begin{array}{c}\text { eq CO} \\
(\mathbf{k g} / \text { tahun })\end{array}$ & $\begin{array}{c}\text { eq CO} \\
\text { (kg/tahun/ton sampah }\end{array}$ \\
\hline Nirmala & 25,00 & 1,87 & 1408,56 & 79,64 \\
\hline Pondok Joang Indah & 15,09 & 1,13 & 850,35 & 93,78 \\
\hline Kumala & 8,86 & 0,66 & 499,46 & 92,13 \\
\hline
\end{tabular}

Tabel 10 menunjukkan total emisi gas rumah kaca dari pemrosesan akhir sampah skenario ketiga.

Tabel 10. Emisi gas rumah kaca dari pemrosesan akhir skenario daur ulang dan pengomposan

\begin{tabular}{|c|c|c|c|c|}
\hline \multirow{2}{*}{ Jenis Perumahan } & Pengomposan & $\begin{array}{c}\begin{array}{c}\text { Penimbunan } \\
\text { Residu }\end{array} \\
\end{array}$ & \multirow{2}{*}{$\begin{array}{c}\text { Total eq } \mathrm{CO}_{2} \\
\text { (kg/tahun) }\end{array}$} & \multirow{2}{*}{$\begin{array}{c}\text { eq } \mathrm{CO}_{2} \\
\text { (kg/tahun/ton } \\
\text { sampah) }\end{array}$} \\
\hline & $\begin{array}{c}\mathrm{eq} \mathrm{CO}_{2} \\
(\mathrm{~kg} / \text { tahun })\end{array}$ & eq $\mathrm{CO}_{2}(\mathrm{~kg} / \mathrm{tahun})$ & & \\
\hline Nirmala & 1408,56 & 3923,34 & 5331,91 & 301,48 \\
\hline Pondok Joang Indah & 850,35 & 1695,30 & 2545,65 & 280,73 \\
\hline Kumala & 499,46 & 1293,04 & 1792,49 & 330,66 \\
\hline
\end{tabular}

Skenario ketiga menghasilkan emisi gas rumah kaca yang paling rendah jika dibandingan pemrosesan akhir sampah pada skenario pertama dan kedua. Jumlah emisi yang dihasilkan dari penimbunan residu sampah di TPA masih lebih tinggi dibandingkan proses pengomposan. Pada 
pengomposan terjadi proses degradasi material organik seperti penimbunan sampah di TPA tetapi dalam kondisi aerobik. Gas rumah kaca yang dihasilkan dari proses dekomposisi material organik cenderung lebih tinggi untuk proses penimbunan dibanding pengomposan (Lou dan Nair, 2009). Selain itu proses pengomposan menghasilkan produk yang ekonomis dan efisien secara ekologis serta dapat membangun sistem pengelolaan sampah dengan siklus tertutup (Zeman et al., 2002). Produk kompos yang dihasilkan akan digunakan untuk menanam tumbuhan dan nantinya yang akan menjadi sampah organik.

Estimasi emisi ekuivalen $\mathrm{CO}_{2}$ per ton sampah basah dengan tiga skenario pemrosesan akhir yang berbeda ditunjukkan pada Gambar 5.

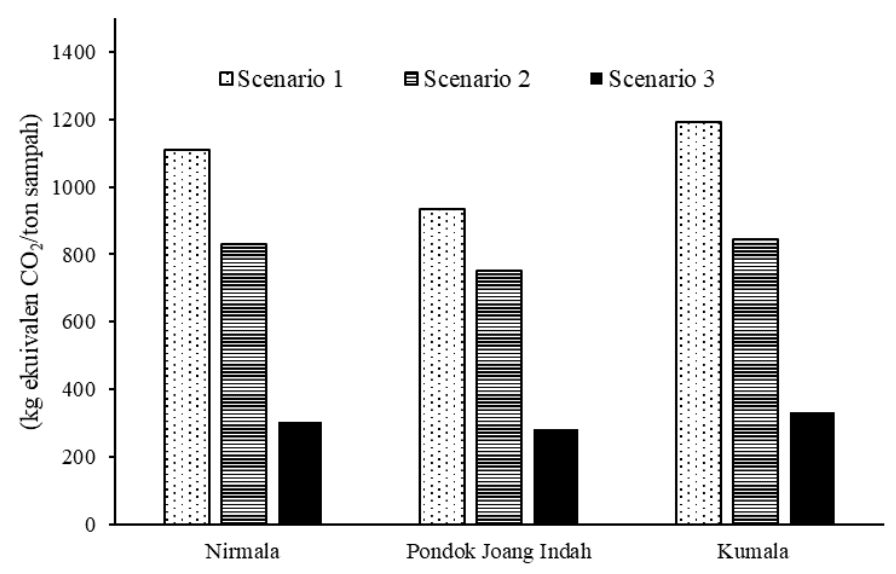

Gambar 5. Emisi ekuivalen $\mathrm{CO}_{2}$ per ton sampah basah dengan proses pemrosesan akhir sampah yang berbeda

Grafik tersebut menunjukkan proses penimbunan sampah di TPA menghasilkan emisi gas rumah kaca yang paling tinggi. Estimasi emisi yang paling tinggi dihasilkan dari sampah yang berasal dari perumahan Nirmala dan Kumala. Emisi ekuivalen $\mathrm{CO}_{2}$ yang dihasilkan adalah 1192,62 kg/ton dan 1109,18 kg/ton sampah basah. Proses daur ulang dan pengomposan sampah dapat mengurangi emisi gas rumah kaca yang dihasilkan dari proses penimbunan sampah di TPA. Penurunan emisi gas rumah kaca yang cukup signifikan dari penimbunan sampah di TPA terjadi jika proses daur ulang diterapkan pada pemrosesan akhir sampah. Hal ini disebabkan persentase sampah organik dan kertas yang tinggi. Jika persentase reduksi sampah yang didaur ulang lebih tinggi, maka emisi gas rumah kaca yang dihasilkan dari proses penimbunan sampah akan menurun. Upaya perubahan pengelolaan sampah dari proses penimbunan di TPA ke proses daur ulang bertujuan untuk mencegah emisi gas rumah kaca yang dihasilkan dari proses 
penimbunan (De La Barrera dan Hooda, 2016). Kondisi Business as Usual (BAU) terdapat pada skenario kedua, di mana 50\% sampah ditimbun di TPA dan 50\% sampah dibakar secara terbuka. Penurunan emisi gas rumah kaca tiga permukiman dari konsidi BAU adalah 63,67\%; $62,67 \%$; dan $60,78 \%$.

\section{KESIMPULAN}

Emisi gas rumah kaca dari kegiatan pengangkutan sampah dari sumber ke TPS bergantung pada jenis kendaraan yang digunakan, kondisi kendaraan, dan jumlah bahan bakar yang digunakan. Emisi gas rumah kaca dari proses penimbunan sampah di TPA ditentukan jumlah dan komposisi sampah yang ditimbun. Sampah organik dan kertas merupakan penyumbang terbesar emisi gas rumah kaca dari proses penimbunan. Jumlah emisi gas $\mathrm{kg}$ ekuivalen $\mathrm{CO}_{2} /$ tahun/ton sampah yang dihasilkan dari ketiga skenario adalah 3237, 2423, dan $913 \mathrm{~kg} / \mathrm{tahun} / \mathrm{ton}$. Untuk mengurangi jumlah emisi gas rumah kaca dari kegiatan penimbunan sampah dan pembakaran sampah secara terbuka, proses daur ulang dan pengomposan perlu dilakukan. Proses daur ulang dan pengomposan sampah dapat menurunkan emisi gas rumah kaca sebesar $62,34 \%$ dari kondisi BAU.

\section{UCAPAN TERIMA KASIH}

Ucapan terima kasih disampaikan kepada Lembaga Penelitian dan Pengabdian Masyarakat Institut Teknologi Kalimantan (LPPM ITK) yang telah mendanai penelitian ini.

\section{DAFTAR PUSTAKA}

Badan Pusat Statistik Kota Balikpapan. (2019). Balikpapan dalam Angka 2019. Balikpapan : Badan Pusat Statistik Kota Balikpapan.

Badan Standarisasi Nasional. (1994). Metode pengambilan dan pengukuran contoh timbulan dan komposisi sampah perkotaan. Jakarta : Badan Standarisasi Nasional.

Banaget, C. K., Frick, B., and Saud, M. (2020). Analysis of Electricity Generation from Landfill Gas (Case Study: Manggar Landfill, Balikpapan). IOP Conference Series : Earth and Environmental Science, 448, 12003.

Cahya, W. I., and Pandebesie, E. S. (2017). Kajian Aspek Teknis dan Finansial Tempat Pengolahan Sampah Terpadu (TPST) Gunung Bahagia, Kota Balikpapan. Jurnal Teknik ITS, 6 (2).

Chaerul, M., Febrianto, A., dan Tomo, H. S. (2020). Peningkatan Kualitas Penghitungan Emisi Gas Rumah Kaca dari Sektor Pengelolaan Sampah dengan Metode IPCC 2006 (Studi 
Kasus: Kota Cilacap). Jurnal Ilmu Lingkungan, 18 (1) : 153 - 161.

Cogut, A. (2016). Open Burning of Waste: A Global Health Disaster. R10 Regions of Climate Action, Switzerland.

Damanhuri. (2010). Diktat kuliah TL-3104 Pengelolaan Sampah. Teknik Lingkungan, Institut Teknologi Bandung

De La Barrera, B., and Hooda, P. S. (2016). Greenhouse Gas Emissions of Waste Management Processes and Options: A Case Study. Waste Management and Research, 34(7) : 658-665. Eisted, R., Larsen, A. W., and Christensen, T. H. (2009). Collection, Transfer and Transport of Waste: Accounting of Greenhouse Gases and Global Warming Contribution. Waste Management and Research, 27(8) : 738-745.

IPCC. (2019). 2019 Refinement to the 2006 IPCC Guidelines for National Greenhouse Gas Inventories. The $49^{\text {th }}$ session of the IPCC Report, The Intergovernmental Panel on Climate Change.

Kementerian Lingkungan Hidup. (2012). Pedoman penyelenggaraan inventarisasi gas rumah kaca nasional. Jakarta : Kementerian Lingkungan Hidup Indonesia.

Kementerian Lingkungan Hidup dan Kehutanan. (2020). Sistem Informasi Pengelolaan Sampah Nasional. Jakarta : Kementerian Lingkungan Hidup Indonesia.

Kustiasih, T., Setyawati, L. M., Anggraeni, F., Darwati, S., and Aryenti, A. (2014). Faktor Penentu Emisi Gas Rumah Kaca dalam Pengelolaan Sampah Perkotaan. Jurnal Permukiman, 9(2) : 78-90.

Kusumawati, P. S., Tang, U. M., and Nurhidayah, T. (2013). Hubungan Jumlah Kendaraan Bermotor, Odometer Kendaraan dan Tahun Pembuatan Kendaraan dengan Emisi $\mathrm{CO}_{2}$ di Kota Pekanbaru. Jurnal Ilmu Lingkungan, 7(1) : 49-59.

Lou, X. F., and Nair, J. (2009). The impact of landfilling and composting on greenhouse gas emissions - A review. Bioresource Technology, 100 (16) : 3792 - 3798.

Myhre, G., Shindell, D., Bréon, F.-M., Collins, W., Fuglestvedt, J., Huang, J., Koch, D., Lamarque, J.-F., Lee, D., Mendoza, B., Nakajima, T., Robock, A., Stephens, G., Takemura, T., and Zhang, H. (2013). Anthropogenic and natural radiative forcing, In Climate Change 2013: The Physical Science Basis, Contribution of Working Group I to the Fifth Assessment Report of the Intergovernmental Panel on Climate Change. Cambridge : Cambridge University Press.

Ningrat, A. A. W. K., Kusuma, I. G. B. W., dan Wayan, I. (2016). Pengaruh Penggunaan Bahan Bakar Pertalite Terhadap Akselerasi Dan Emisi Gas Buang Pada Sepeda Motor 
Bertransmisi Otomatis. Jurnal Mettek, 2(1) : 59 - 67.

Purwaningrum, P., Pratama, I., dan Handoko, W. (2014). Desain Pengembangan Landfill Zona

3 , Studi Kasus Landfill Manggar Balikpapan. Jurnal Teknologi Lingkungan, 5(5) : 159 166.

Rachman, I., and Matsumoto, T. (2015). Study On Environmental Consciousness And Waste And Wastewater Management Of Household In Rural Area Balikpapan City In Indonesia. Proceeding of Environmental Systems Research, 43, 97-104.

Ratya, H., dan Herumurti, W. (2017). Timbulan dan Komposisi Sampah Rumah Tangga di Kecamatan Rungkut Surabaya. Jurnal Teknik ITS, 6(2), C451-C453.

Vergara, S. E., and Tchobanoglous, G. (2012). Municipal Solid Waste and The Environment: A Global Perspective. Annual Review of Environment and Resources, 37 (1) : 277-309.

Wiedinmyer, C., Yokelson, R. J., and Gullett, B. K. (2014). Global Emissions of Trace Gases, Particulate Matter, and Hazardous Air Pollutants from Open Burning of Domestic Waste. Environmental Science and Technology, 48(16) : 9523-9530.

Zeman, C., Depken, D., and Rich, M. (2002). Research on How The Composting Process Impacts Greenhouse Gas Emissions and Global Warming. Compost Science and Utilization, 10(1) : 72 - 86. 